\title{
Advancing English Language Education Policy in Consideration of Multilingualism on National Integration in Nigeria
}

\author{
Chioma Vivienne Nwokoro, PhD. \\ Eastern Palm University \\ Nigeria \\ Felix Onwubuariri Chima, PhD. \\ Prairie View A\&M University \\ United States of America \\ Adaku Agnes Ubelejit-Nte, PhD \\ University of Port Harcourt \\ Nigeria \\ Edeosa O. Enobakhare \\ Benson Idahosa University \\ Nigeria \\ Uchem, Obinna Joseph \\ Eastern Palm University \\ Nigeria
}

\begin{abstract}
This paper is an exposition of the effects of multilingualism on national integration in Nigeria and the need for advancing English language education policy. Ever since its independence, Nigeria is yet to achieve the value of oneness and unity in diversity. The insurgence of ethno-cultural, religious, political, economic, and other tensions and conflicts in Nigeria have continued to undermine concerted efforts to achieve the desired national integration in Nigeria. In this paper, we argued that much like other ethnocentric dividing factors, the state of multilingualism in Nigeria has further led to ethnic division and national disintegration. Thus, the paper stresses on the value of strengthening English language education policy in Nigeria. The paper highlighted some of the challenges in maintaining English language as a medium of learning in Nigerian schools, past and present; and went further to suggest that a central language of communication and learning like English can encourage cohabitation and acceptance among the various ethnic groups. The paper identified those features of ethnic languages that militate against proper national integration within a single polity. The paper stresses that national integration can be achieved if Nigerians depoliticize language policy in the country, and emphasize on how English language as a common element can foster unity, understanding and development. The paper revealed the benefits English language policy in Nigeria can offer not just in national integration, but also in the advancement of the country in the international community.
\end{abstract}

Key words: National integration, multilingualism, English language policy, language planning, language in society

\section{Introduction}

The primary function of human language is to perform communication functions in the society. For some scholars, (Ogunwale, 2013; Hornby, 1999; Aja Akpuru-Aja, 2008), language can perform other ancillary functions such as an ethnic identifier and a unifying factor. Thus, in whatever way it is evaluated, we find that human language is very important in every society. Nigeria is a multi-lingual society, where more than 400 indigenous languages are spoken and used for communication among the different ethnic groups (Danladi, 2013; Ouane and Glanz, 2010). These languages used at the family and communal levels, tend to promote unity and bonding among the indigenous people, but unfortunately not among the different ethnic groups (Ndukwe, 2013). In Nigeria, language differences have caused mistrust, conflict and ethnic division, which threaten the fabric of the nation (Shobomehin, 2002). In multiethnic suburban areas like Lagos, Abuja and Kaduna, though people of different ethnic groups live together, they virtually distrust each other, and the use of indigenous languages only breed distrust, possible violence and disintegration(Fatile and Adejuwon, 2012). Thus, any diversion to the use of indigenous languages in urban cities is viewed with distrust (Shobomehin, 2002). 
To deal with disintegration due to ethnic divide, English language was introduced as the major teaching language in Nigeria schools (from primary to tertiary institutions) in 1977 (see Federal Republic of Nigeria National Policy on Education 1977, and section 97 of 1999 Constitution of Federal Republic of Nigeria) (cited in Adebanyu, 2004).The NPE (1977) explicitly stated that for national integration and cohesion, English language would be the medium for instruction and learning in all schools in Nigeria. Communication in schools also followed the same suit. Nonetheless, despite the use of English language as medium for teaching at all levels of education in Nigeria today, the question remains why the ethnic divide and disintegration in the society still exist. Moreover, there is notable resistance to the use of English language as medium of instruction in some parts of the country (Muhammad et al, 2018; Bamgbade, 2012), which has triggered off the need for this study.

This study in addressing these issues will look at the state of the English language Policy in Nigeria, the contending issues in its implementation as medium for instructions in Nigerian schools today, and the role it plays in ensuring national integration in the country. It will go further to proffer ways of strengthening the use of English language in school instructions. This is with the intention of dealing with the delicate state of the nation aggravated by conflicts, mistrusts and ethnic dichotomies. The rest of the essay is organized as follows; the next section provides the definitions of concepts as it reflects the context of the paper. The third section discusses the effects of multilingualism on national integration in Nigeria. The fourth section deals with the context of English language in Nigeria, as well as the state of English language education policy in Nigeria. The fifth section highlights the contending issues in the use of English as medium for instructions in Nigeria schools, with special attention paid on past and recent debates. The sixth section discusses the ways forward in strengthening the policy of English language education for national integration in Nigeria. The last section is the conclusion.

\section{Definition of Concepts}

\section{i. Language and Society}

Every language use is situated within a group of speakers in the society. They may be people living in the same community who may share the same origin and native tongue, belonging to the same profession or social class, or may be of different ethnic background cohabiting together in a given location. Since language is a system of symbols, the speakers chose those symbols that will communicate something meaningful to them (Downes, 1984). Hence, language is considered a symbol of communication. Language cannot exist or develop outside society. The relationship between the two is that of interdependence. To ignore the influence of language on society or of society on language would give only an incomplete picture of the relationship that language and society share. Therefore, the main concern of sociologists is to examine this complex relationship between language and society. Downes (1984) suggested some of the questions that sociologists should be concerned with in the study of language in society. These includes, is language static or variable? To what extent are social factors responsible for language variation? How is it that people are able to communicate despite variation? Are standard languages different from dialects? Why should each social context be examined in its own right? Are there any homogenous societies in reality? Can language be used as a tool for power in all spheres of social life, like education, religion, and administration, etc., and lead to social exploitation or exclusion? Can language initiate a social change? Why do languages change? Is language planning essential? What is the essence of language policy? As diverse orientations as these may be, they help us to reflect on the nature of language and society, and realize how in reality the relationship between the two is inextricably interwoven. Although these questions will not be addressed in this study, however these interests of sociologists in language give an understanding of the essence of this study.

\section{Multilingualism}

Multilingualism is a complex phenomenon that has been studied in various disciplines such as linguistics, psycholinguistics, sociolinguistics, and sociology of language. There are many definitions of multilingualism. A wellknown definition of multilingualism is given by the European Commission (2007:6): "the ability of societies, institutions, groups and individuals to engage, on a regular basis, with more than one language in their day-to-day lives". In other words, multilingualism refers to diversity of tongue and this definition of multilingualism is relevant for discussing some of its dimensions in society. Moreover, multilingualism depicts group of people though having different languages cohabiting together. According to Aronin and Singleton (2008), some of the relevant questions, sociologists would be interested on in the study of multilingualism focus on how diversity of language in society could lead to either social cohesion or instability. Alternatively, does language differences among people cohabiting together lead to disintegration or integration of members of the society? This essentially characterizes the objective of this paper. 


\section{iii. $\quad$ National Integration}

National integration has been defined in many ways and tend to refer to topic surrounding nation-building, national unity, national cohesion, national loyalty, or the national question. Otite (2000:118) asserts that it "involves consensus on the limits of the political community and on the nature of the political regime". In this definition, it connotes the forging of agreement among the members of a state on the extent of unity they wish to have as well as the type of political structure and institutions they desire. Duverger (1976:177) sees it as a "process of unifying a society which tends to make it a harmonious city, based on an order its members regard as equitably harmonious". This entails that integration promotes smooth interaction among the members of society based on certain established principles of fairness, social justice, and cohabitation.

According to Ethiopia (2014:63), "national integration indicates a relationship of community among people within the same political entity, as well as a state of mind or disposition to be cohesive, to act together, and to be committed to mutual programs". Therefore, this explains that national integration depicts a society of oneness whose members are willing to live and work together harmoniously and share the same destiny. In this process, members of the social system develop an escalating sequence of contact, cooperation, consensus and community (Ojo, 2005:51). It has been argued that a society is integrated when "(a) it has effective control over the use of the means of violence; (b) it has a center of decision making capable of effecting the allocation of resources and rewards; and (c) it is a dominant focus of political identification for a large majority of politically aware citizens" (Etzioni, 1965:4 cited in Ojo, 2005:51). Essentially, the willingness to live together in peace or in conflict is what makes national integration a significant and relevant topic in sociology of political life.

\section{Language Policy}

Johnson (2013) citing Schiffman (1996: 276), viewed language policy in both legal and cultural constructs. From a legal construct, Johnson (2013) opined that Schiffman construed language policy as consisting of various elements of an explicit nature - juridical, judicial, administrative, constitutional and/or legal language. On the other hand, language policy as a cultural construct rests primarily on other conceptual elements - belief systems, attitudes, myths - the whole complex that we are referring to as linguistic culture, which is the sum totality of ideas, values, beliefs, attitudes, prejudices, religious strictures, and all the other cultural 'baggage' that speakers bring to their dealings with language from their background. In another context, Kaplan and Badaulf (1997: xi) argued that language policy is the exercise of language planning which leads to, or is directed by, the promulgation of a language policy by government (or other authoritative body or person).Johnson (2013) view, which is entrenched with complexities of culture, value and social cohesion, reflects the totality of the relevance of language policy in the development and consolidation of a society. On the other hand, Kalplan and Badaulf (1997) definitions construed language policy as a body of ideas, laws, regulations, rules and practices intended to achieve the planned language change in the societies, group or system.

From the two definitions, what is understood is that language policy is essential part of society, and enables proper planning of language use in that society. A complicating question is the relationship between language policy and the term that preceded it, language planning. Most scholars agree that language policy and language planning are closely related but have different activities. Some argue that language planning subsumes language policy (Kaplan and Baldauf 1997), while others argue that language policy subsumes language planning (Johnson, 2013). However, in this study we view language policy as a component of language planning.

\section{The Effects of Multilingualism on National Integration in Nigeria}

Linguistic pluralism based on ethnic origins has been at the base of Nigeria's political problem since amalgamation in 1914. Nigeria a former colony of Britain was created as a nation, with the amalgamation of the then southern and northern colonies in 1914. The colonial policy demarcated the country along ethno linguistic pluralism, which has since led to political instability in the country. Nigeria has over 400 indigenous spoken languages among the ethnic groups scattered all over the country (Danladi, 2013; Ouane and Glanz, 2010). In some cases, the number of indigenous spoken languages in Nigeria cannot be numbered. Arua (2003:135) puts it this way, "we cannot promptly specify the number of languages spoken in Nigeria as a nation". Although enriched with multilingual assets, however, none of these languages has become a source for integration, nor have multilingualism in the country provoked unity among the divided people of Nigeria today (Danladi, 2013).In fact, the language differences has further created big gap in the integration of trust, communality and unity among the ethnic groups.

Elaigwu, (1987) defined national integration as the capacity of different members or groups in a plural society to adapt to the demands of national existence while co-existing harmoniously. Therefore, national integration means the recognition of oneness even when people coexist in diversity. Some scholars (Danladi, 2013; Babajide, 2001; 
Adegbija, 2008) writing on Nigeria's multi linguistic context, argue that adopting any of the tribal languages as lingua Franca would constitute disaster to national development and integration. Their arguments are mostly based on how language differences and ethnic divisions have raved various devastations in the nation, such as war, ethno-religious conflicts and violence. Adegbija (2008) argued that for national integration, cohesion, and development to thrive, there must be a language capable and acceptable by all in the administration of a country's affairs, and advocated for English language to remain the official language.

The struggle for a unified Nigeria should start with the recognition of English language by all peoples of the nation. The recent revolts and resistance in some parts of the country, especially in the Northern part, towards the usage of English language for instructions in schools only threaten the national unity (Ogunwale, 2013). Lack of a unifying factor has done grievous harm to the existing statuesque of peace in the country, and all are traceable to ethnic and religious differences. Moreover, these ethnic distrusts find expression in some language uses that embody prejudice, intolerance, ethnocentrism and discrimination. For instance, there are prejudiced expressions such as "Nyamiri", "Kobo Kobo", "Igbo sense", "Ofe Nmanu", "Mgbati Mgbati", "Ewu Hausa or Aboki nama", which are derogatively used to refer to certain ethnic groups.

Given the obvious disunity that may result from multilingual usage in Nigeria, it is pertinent to address how English language education should be more strengthened and facilitated for national integration in Nigeria.

\section{The Status of English Language in Nigeria}

English language could be seen as the live wire of the Nigerian society, because it has come to occupy a good position in life of the people (Arua, 2003; Akindele and Adegbite, 2005). However, this does not imply that the indigenous languages are inferior to English language; but rather, English language has come to fill a huge communication gap due to multilinguistic state of the country. In addition, English language use in the country has facilitated contact between Nigerians of diverse language backgrounds. To this end, English has remained the official language of the country, the language of official documents, and official communication.

About the origin of English language usage in Nigeria, some authors contend that this cannot be ascertained. For example, Ogu (1992:56) argued that to say colonialism birthed the use of English language in Nigeria is like shedding away a whole lot of history about the people's previous contacts with the British. Babajide (2001) asserted that it is certain that as at 13th century, the precolonial people of Nigeria had already made contact with Europeans. The Europeans, including the English merchants, paid occasional transatlantic trade visits to the precolonial peoples of Nigeria that lived mostly in coastal areas, such as the ijaws, kalabaris, edos and itsekiris, urhobos, bonni, Efik, Ibibio, and the arochukwu people amongst the Ibo tribe (Ndukwe, 2015b). Mostly, the people who lived in the coastal regions had major contacts and retained cordiality with the English and other European traders, especially during the slave trade period (Ogunsiji, 2004). It is expected that with these contacts with English people, the precolonial peoples of Nigeria must have learnt a way of communicating with their trade partners.

Notwithstanding, most literature maintain that English language assumed a national status in Nigeria through colonialism (Ojo, 2010; Adeyanju, 2004; Yusuf, 2012; Quirk et al., 1985). With the amalgamation of the then northern and southern colonies in 1914, there was a need for cohesion and unifying language, of which English language being the colonial administrator fitted well into (Adeyanju, 2004). Thus, English language became the official language in the country and was retained even after independence (Adeyanju, 2004). The British colonial administrator formulated policies that would guide the processes of establishing a lingua franca in Nigeria, especially in education, offices, law courts and all levels of government administration (Ojo, 2010). The missionaries further exacerbated the use of the English language in missionary schools established during the colonial period (Quirk et al., 1985). Thus, the actual implantation of English language in Nigeria was actualized through the precolonial transatlantic trade, colonial administration, and missionary education.

\section{English Language Education Policy in Nigeria}

Most policy on language use in multilinguistic societies results from the need for national integration, and to resolve the communication problems (Blench 2002; Musa, 2010; Ojo, 2010). Policy on language use is significant in multiethnic society, since it brings about the needed planning, cohesion and integration (Ndukwe, 2015a; Oyewole, 1998). It brings cohesion in the national level, and existentiality or acceptability of the society in the global community.

The first policy on English education in Nigeria was promulgated in 1927 during the colonial era when the British advisory on education suggested the implementation of a national language for instructions in the already established schools in the colony (Blench, 2002; Adeyanju, 2004; Mohammad et al., 2018). This policy was established to allow the British colonialist retain a common language for easy administration in offices and for teaching in the new schools (Jalaludeen and Gwandu, 2016). 
Subsequently, English language was encouraged as the language for instructions, communication and learning in the new schools established by the missionaries. After independence in 1960, the 1961 National Policy on Education was promulgated, and the use of English language as a lingua franca and for national unity was initiated in order to maintain a one-Nigerian status (Musa, 2010).

The 1961 policy unlike the colonial policy was focused on national unity (Musa, 2010). The next policy was formulated in 1977. Unfortunately, the 1977 policy on English language was ethnic flaunted as it emphasized the usage of the indigenous languages at first three years of teaching, while the English language became medium for instructions after the first three years of learning in schools (Adeyanju, 2004; Omontoyibo, 2015). Although the 1977 policy actually assigned different functions to the various languages used in country- (where it placed English language as the official language and the indigenous languages as language for acculturalization of citizens), it was seen as biased with ethnic consciousness (Adeyanju, 2004).

Eventually the1977 policy on English language education faced various criticisms, as it was considered ambiguous and complex. It was later replaced by the 1998 policy (Omotonyibo, 2015; Obuasi, 2006).The 1998 and 2004 policy on English language education recognized that retaining English language as medium for learning and instructions at all levels of education in the country would enable building of character, civility, unity and patriotism among the people (Musa, 2010). The policy also ensured the provision of equal opportunities for all Nigerians to learn English at all educational levels in the country (Ojo, 2010). These later policies gave English language primacy at all levels of education in the country. Notwithstanding, there are still observed negative reactions to the use of English for instructions at all levels of education in some parts of Nigeria. This is discussed in the next section.

\section{English as medium of instruction in Nigerian schools - The contending issues}

There is recent debate on the issue of English language as the official language or language of education in Nigeria (Yusuf, 2012). It is becoming more problematic issue with regards to finding the one language alternative to replace it by scholars as each suggestion is fraught with controversies (Yusuf, 2012). In various education policy planning and deliberations, the use of indigenous languages for instructions in Nigerian schools has been suggested and submitted (Enahoro, 2002). Most of the submissions were either ethnic biased, anti-western culture, or out of the need to follow up with the communique at the Pan African summit on linguistic use in Africa, which aimed at expunging Africa of all colonial languages (Muhammad et al., 2018; Jalaludeen and Gwandu, 2016).

In 1961 when some of the members of parliament debated whether the three major tribal languages - Igbo, Yoruba or Hausa could be adopted as language for instructions in schools, there was great resistance (Gwandu, 2016). This is because the initiative threatened national unity of the country that just got its independence (Enahoro, 2002).Until date(as evident in Enahoro, 2002, Yusuf, 2012), the three major indigenous languages or even the minority languages have no candidacy since population is a key factor in language planning. Muhammad et al. (2018), Evue, (2013), Enahoro (2002), and Yusuf (2012) argued that even the suggestion for the use of the hybrid 'WAZOBIA' or the 'Pidgin-English' spoken everywhere in the country was viewed with disparagement, and refused in the policy planning (Omontonyibo, 2015). With the recent volatile incidence in the socio-political domain, English now, more than ever before, is very critical in avoiding disintegration and threat to the country's existence (Omotonyibo, 2015). Although there is still uneasiness in choosing a colonial language as primary language in a country already ravished by the same colonialism; however, national integration was more prioritized in the planning (Omotoyinbo, 2015).

\section{Strengthening English Language Education Policy for National Integration in Nigeria}

Given that there is still contending issues to the acceptance of English language as major medium of instruction in Nigerian schools, this study will offer various ways policy in English language education can be strengthened for national integration in Nigeria. Language policy planning is a critical issue in the sociopolitical setting of any country (Ndukwe, 2015a). The sensitive and technical nature of policy making, require continuous negotiation, consensus and workability (LoBianco, 1990). Since Nigeria is a multilinguistic country it is imperative that language policy in the country will be sensitively planned and executed to avoid controversies. Policy makers need to be cautious when it involves formulation of language policies to avoid replicating the language riot in Ethiopia (Woldermariam, 2007).

Thus, in this study, we suggest that the first action towards strengthening English language education policy for national integration is by engaging the requisite people at all levels of the planning and implementation. In a democratic setting of which Nigeria claim to be, people must be able to participate in deliberations of issues that concern them. Although instructions in schools are mostly done by educationists, yet these educationists are not allowed to be part of the deliberations at all levels of government. Hence, the pertinent question is - where does the school teachers come in the planning? The various deliberations from 1961 to present on the role of English language in schools have been the domain of politicians, who are mostly uneducated, and have less understanding about learning. 
Moreover, at all levels of policy planning, other important actors, such as the media and pressure groups, should be encouraged to analyze and address limitations before implementation is carried out.

Secondly, there is need for a common ground where every party understands the value of English language in the country. Lo Bianco (1990:8) cited in Omontoyibo (2015:82) noted that "policy making is not a technical application of formulae, but rather one of negotiating the consensus, of haggling out workable agreements about desired outcomes on language questions." The value of English language for unity in Nigeria should not be deemphasized. Most of the attacks towards the use of English bear ethnic bias. The initial acceptance of English language as lingua franca in Nigeria was intended to eliminate threats of division; hence, dabbling with the consciousness of the use of indigenous languages in schools can only wake up the sleeping dog.

Thirdly, national policies are promulgated to address the impending situation in any country (Omontoyibo, 2015). The state of conflict and insecurity due to ethnic and religious divisions and rivalries in Nigeria require language policy that will ensure unity and progress among the ethnic groups. Therefore, policy on language use in schools should be sensitive to the recent issues facing the country and less ethnic biased. It requires disciplined planners who have one target, which is to reduce the problem, and facilitate actions for positive progress. A language policy must be able to fit the demand of a nation, and as it is, Nigeria needs peace and unity, and the integration of the young ones to oneNigerian orientation. Moreover, a unifying language like English can bring this, because it is a collective language.

Ojo (2010) noted that language as a political instrument allows countries to have access to global resources, connections and wealth. Thus, the major concern in the promulgation of language policy should be its relevance in the world. Nigerian indigenous languages are traditional, thus, cannot effectively engage international linkages. The ability to speak an advanced language like English has its prestige in international level, since advanced languages such as French, English, Spanish, German etc., are considered to be language of politically and economically dominant groups. Hence, the political, global and economic relevance of English language should be given more priority in the policy planning.

\section{Conclusion}

This paper in contributing to knowledge has located the distinct place of English language in the on-going quest for national integration in Nigeria. The paper highlighted the importance of English language education policy in building and sustaining national integration in Nigeria. This is with special attention paid on the recent criticisms towards the use of English for instructing students in Nigerian schools. The paper suggests that since Nigeria is a multiethnic society, it is essential and integrative to use a common language like English for school instructions, and one, which has capacity to advance the country in national and international levels. Developing a policy that maintains English language as the medium for instruction in Nigerian schools will ensure conditions for effective national consolidation and integration. As this paper opined, this policy should gear towards resolutions of those problems and differences in acceptance of English language, especially now the country is rife with ethnic conflicts. The paper insists that adopting a central language for instruction in schools in Nigeria will encourage mutual respect and ability to co-exist peacefully.

\section{References}

Adegbija, E. (2008). Language Policy and Planning in Nigeria. Current Issues in Language Planning, 5(3), 181-246. Adeyanju, D. (2004). Historicity and language function: a case of the English language in Nigeria. In Oyeleye. L. (Ed.) Language and Discourse in Society. 62-70.

Aja Akpuru Aja (2008). Language, Culture and Power Politics: Lessons for the Promotion of Nigerian Language and Culture; A realist Analysis. Journal of Nigeria Languages and Culture, I (10), 1-5

Akindele, F. and Adegbite, W. (2005). The Sociology and Politics of English in Nigeria. Ile-Ife: O.A.U. Press.

Aronin, L., \& Singleton, D. (2008). Multilingualism as a new linguistic dispensation. International Journal of Multilingualism, 5, 1-16.

Arua, A. (2004). Botswana English: Some syntactic and lexical features. English World Wide, 25(2), 255-272.

Babajide, A. (2001). Language attitude patterns of Nigerians. In Igboanusi, H. (Ed), LanguageAttitude and language conflict in West Africa. Ibadan: Enicrownfit Publishers, $1-3$.

Bamgbade O. (2012). Some Issues of English Language in Nigeria. University of Ibadan, Linguistics Departmental Seminar.

Blench, R. (2002). Research on minority languages in Nigeria. In FEL Newsletter Ognios. May, 11-13

Danladi S. S. (2013). Language policy: Nigeria and the role of English language in the 2st century. European ScientificJournal, 9 (17), 1-21

Downes, W. (1984). Language and Society. Cambridge: Cambridge University Press 
Duverger, M. (1976). The Study of Politics. Hong Kong: Nelson Political Science Library.

Elaigwu J. (1987), "The Challenges of Unity in a Heterogeneous Society” Development Studies Review, 2 (1), 1-20

Enahoro, A. (2002). "Towards a new constitutional order” in Vanguard. Lagos: July, 18-19.

Ethiopia, B. (2014). National Integration, Citizenship, Political Participation and Democratic Stability in Nigeria. An International Journal of Arts and Humanities, 3 (3), 61-82

Evue, A. (2013). Challenges facing the teaching of English language in secondary schools in

Aniocha south local government area of Delta state Nigeria. African Education Indices, 5 (1), 35-42

Fatile, J. and Adejuwon, K. (2012), Niger Delta and the Struggle for Resource Control: What

Implication for National Integration, in Osuntokun, A and Ukaogo, V. (ed.), Niger Delta: Politics of Despair, Deprivation and Desperation, ICS Services Ltd, Lagos

Hornby, A. (1999). Oxford Advanced Learners Dictionary of Current English. $6^{\text {th }}$ Edition. Oxford: Oxford University Press

Jalaludeen, I. \& Gwandu, S. (2016). Language policy on education in Nigeria: Challenges of multilingual education and future of English language. American Research Journal of English and Literature, 2.

Johnson, D. (2013). What is language policy? London: Palgrave Macmillan.

Kaplan, R. and Baldauf, R. (1997). Language planning from practice to theory. Multilingual Matters, 108,

Lo Bianco, J. (1990). Making language policy: Australia's experience. In Baldauf, R and Luke, A. (Eds.), Language planning and education in Australasia and the South Pacific. Philadelphia: Clevedon, 47-79.

Muhammad, H., Ya'u, S., Aliyu, U. and Hassan, M. (2018). Teaching and learning English language in Nigerian schools: importance and challenges. Teacher Education and Curriculum Studies, 3(1), 10-13.

Musa, R. (2010). The role of mother tongue education in National Development. In Osakwe,

E. (ed), Social Studies and Integrated National Development in Nigeria, 75 - 82. Kaduna: Jenvis Press National Policy on Education (NPE) (1977). Federal Republic of Nigeria [FGN]. Lagos: Federal Government Press

Ndukwe, J. (2015). The Question of a National Language in National Development. Journal of Humanities and Social Science 20 (10), 75-79

Ndukwe, J. (2015). National language policy on primary education and the challenges of language teaching and learning in the UBE programme. International Journal of Humanities \& Social Science Studies 2 (2), 134-140.

Obuasi, I. (2006). The Place of language in Nigeria's Reform Agenda. Nsukka: UNN Press Ltd.

Ogu, J. (1992). A Historical survey of English and the Nigerian situation. Yaba: Kraft BookLimited.

Ogunsiji, A. (2004). Status, features, and functions of English in Nigeria and their implications for EL2 teaching/learning. In Oyeleye, L. (Ed), Language and discourse in society. Ibadan: Hope Publication Ltd. pp. $83-97$

Ogunwale, A. (2013). Harnessing multilingualism in Nigeria for development: The challenges and strategies. International journal of English and literature 4 (9), 367-374

Ojo, E. (2010). National language policy and the search for national integration in Nigeria. The Open Social Science Journal, 3, 1-5.

Ojo, E. (2005). Federalism and National Cohesion in Nigeria. In Ebere Onwudiwe and Rotimi Suberu (Eds.). Nigerian Federalism in Crisis: Critical Perspectives and Political Options. Ibadan: Programme on Ethnic and Federal Studies, University of Ibadan

Omotoyinbo, D. (2015). Language policy in Nigeria: Prospect for national unity. International Journal of Society, Culture \& Language, 4(1), 80-88.

Otite, O. (2000). Ethnic Pluralism and Ethnicity in Nigeria. Ibadan: Shaneson C.I. Ltd.

Ouane A, Glanz C (2010). Why and How Africa Should Invest in African Languages and Multilingual Education. UNESCO Institute for Lifelong Learning. Association for the Development of Education in Africa.

Oyewole, A. (1998). Nigerian language for national development. Ibadan: Woliyem Communications.

Quirk, R., Greenbaum, S., Leech, G., and Svarktvik, J. (1985). A Comprehensive Grammar of the English language. London: Longman.

Shobomehin, T.O. (2002), Towards an Integrated National Policy for National Development in

Multilingual Nigeria (A Paper Presented at First English Language Teaching today held at Federal University of Technology, Akure, 2nd - 5th, 2002).

Woldemariam, H. (2007). The challenges of mother-tongue education in Ethiopia: The case of North Omo area. Language Matters: Studies in the Languages of Africa, 38(2), 210-235.

Yusuf, H. (2012). Language as a tool for national integration: the case of English language in Nigeria. International Journal of Applied Linguistics and English Literature, 1(5), 194-201. 